\section{References}

1 Andrews, J, and McGarry, J M, Fournal of Obstetrics and Gynaecology of the British Commonwealth, 1972, 79, 1057.

${ }^{2}$ Larson, P S, Haag, H B, and Silvette, H, Tobacco, Experimental and Chemical Studies, p 390. Baltimore, Williams and Williams, 1961.

3 Cole, P V, Hawkins, L H, and Roberts, D, Fournal of Obstetrics and Gynaecology of the British Commonwealth, 1972, 79, 782.

4 Astrup, P, et al, Lancet, 1972, 2, 1220.

5 Magee, P N, Montesano, R, and Pressman, R, Chemical Carcinogens, ed C E Searle, ACS Monograph Series No 173. Washington, American Chemical Society, 1976.
- Yerushalmy, J, American fournal of Obstetrics and Gynecology, 1964, 88, 505.

7 Mulcahy, R, and Knaggs, J F, American Fournal of Obstetrics and Gynecology, 1968, 101, 844 .

${ }^{8}$ Kelsey, J L, et al, fournal of Epidemiology and Community Health, 1978, 32, 102.

${ }^{9}$ Choi, M, and Klaponski, S, Neurology, 1970, 20, 399.

10 Duncan, A S, et al, The Cardiff Births Survey. In preparation.

11 Capoll, P S, Health Trends, 1978, 10, 49.

12 Edwards, J H, British fournal of Social Medicine, 1958, 12, 15.

(Accepted 15 fune 1979)

\title{
Autonomic neuropathy in rheumatoid arthritis
}

\author{
M E EDMONDS, T C JONES, W A SAUNDERS, R D STURROCK
}

British Medical fournal, 1979, 2, 173-175

the heart-rate response to the Valsalva manoeuvre ${ }^{5}$ and beat-tobeat variation in heart rate with respiration. ${ }^{6}$

\section{Summary and conclusions}

Patients with seropositive and seronegative rheumatoid arthritis (RA) and age-matched controls were investigated for the presence of autonomic neuropathy. Significantly more patients with RA had abnormal autonomic function, suggesting that autonomic neuropathy occurs more commonly in RA than hitherto suspected.

The existence of an autonomic neuropathy may be an important complicating factor in rheumatoid disease and may lead to increased morbidity and mortality.

\section{Introduction}

Peripheral neuropathy is a well-described complication of rheumatoid arthritis (RA), ${ }^{1}$ but few reports on autonomic neuropathy exist. In 1963 Kalliomäki et al ${ }^{2}$ showed a deficient sweating response to an intradermal injection of nicotine in patients with RA. In 1965 Bennett and Scott $^{3}$ found areas of deficient sweating corresponding to cutaneous sensory disease in patients with seropositive RA with peripheral neuropathy but did not examine seronegative patients. In three of their patients a deficient sweating response was found in the absence of peripheral neuropathy, suggesting the presence of a lone autonomic neuropathy. We investigated patients with RA by assessing the integrity of their cardiovascular reflexes. The principal investigation comprised monitoring the immediate heart-rate response to standing as described by Ewing et al, ${ }^{4}$ who found that the normal response of an initial tachycardia followed by a relative bradycardia was absent in diabetics with autonomic neuropathy. To test autonomic function further we investigated

University Department of Therapeutics and Rheumatology, Westminster Medical School, St Stephens Hospital, London SW10 9TH

M E EDMONDS, BSC, MRCP, registrar

T C JONES, medical physics technician

W A SAUNDERS, MD, MRCP, senior registrar

R D STURROCK, MD, MRCP, senior lecturer and consultant

\section{Subjects and methods}

We investigated 68 subjects and divided them into four groups: patients with classical and definite RA, ${ }^{7}$ both seropositive and seronegative (mean age 54.6 (range 22-67) years); patients with osteoarthritis (mean age 54.2 (range 42-65) years); old controls (mean age $51 \cdot 0$ (range 41-67) years); and young controls (mean age 24.6 (range 20-28) years). Before any investigations were done each subject was interviewed and had a full clinical examination. Patients receiving drugs influencing cardiac rhythm were excluded. All subjects were normotensive, not anaemic, and not in cardiac failure. The immediate heart-rate response to standing was measured as described by Ewing et $a l .{ }^{4}$ To quantitate the response we calculated the R-R ratio as follows:

$$
\mathrm{R}-\mathrm{R} \text { ratio }=\frac{\mathrm{R}-\mathrm{R} \text { interval at time of maximum bradycardia }}{\mathrm{R}-\mathrm{R} \text { interval at time of maximum tachycardia }}
$$

In our subjects the mean maximum bradycardia occurred 25 beats after standing and the mean maximum tachycardia five beats after standing. In the study of Ewing $e t \mathrm{al}^{4}$ the mean maximum bradycardia occurred 30 beats after standing and the mean maximum tachycardia 15 beats after standing, giving their ratio of 30:15.

The Valsalva manoeuvre was performed in a standardised manner and the heart rate recorded continuously throughout the strain period and for a further 20 seconds. The changes in heart rate were expressed as the ratio of the maximum tachycardia to the maximum bradycardia - that is, the Valsalva ratio. This test was performed on 12 subjects (10 patients with RA and two young controls). Beat-to-beat variation with respiration was recorded by the method of Wheeler and Watkins ${ }^{6}$ using a Cardiac Recorders Cardiorater Type 64 and a Flat Bed Chart Recorder. The subjects were instructed to breathe deeply at a rate of 6-8 breaths/min, and the beat-to-beat variation was calculated by measuring the difference between maximum and minimum heart rates.

\section{Results}

Immediate heart-rate response to standing-Fig 1 shows the heartrate response to standing in the four groups, with a characteristic tachycardia and relative bradycardia most pronounced in the young controls but also present in the group with osteoarthritis and the old controls. The response was least pronounced in the patients with RA. Fig 2 shows the individual R-R ratios in the four groups. The scatter was wide in each group. Ten patients (nine with RA and one old control) had an R-R ratio of one or less-that is, an abnormal value. There was a significant difference in the mean $R-R$ ratio between the 
patients with RA and those with osteoarthritis and between the patients with RA and the old controls (table I). Table II gives clinical details of the nine patients with RA who had an abnormal R-R ratio, and table III compares these patients with the others with RA-that is, with those without autonomic neuropathy.

Valsalva manoeuvre - The Valsalva manoeuvre was measured in 12

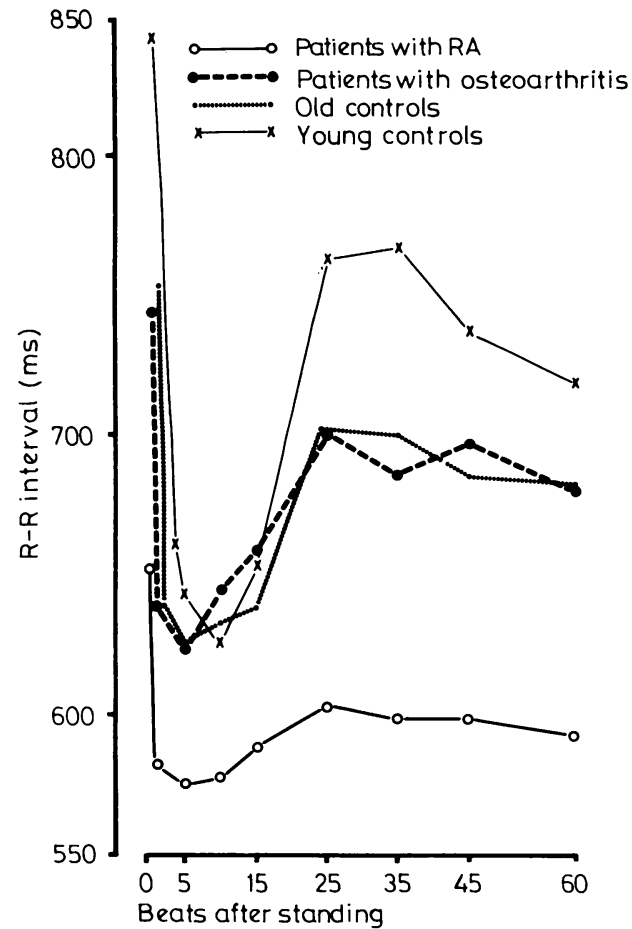

FIG 1 -Mean $R-R$ intervals in first 60 beats after standing.

TABLE I-Number of patients and mean $R-R$ ratio in each group studied

\begin{tabular}{lcccc}
\hline & $\begin{array}{c}\text { Patients with } \\
\mathrm{RA}\end{array}$ & $\begin{array}{c}\text { Patients with } \\
\text { osteoarthritis }\end{array}$ & $\begin{array}{c}\text { Old } \\
\text { controls }\end{array}$ & $\begin{array}{c}\text { Young } \\
\text { controls }\end{array}$ \\
\hline $\begin{array}{l}\text { No in group } \\
\begin{array}{l}\text { Mean }( \pm S D) \\
\text { ratio }\end{array}\end{array}$ & 27 & 13 & 13 & 15 \\
\hline
\end{tabular}

Significance of difference (Mann Whitney $U$ test) compared with patients with RA : ${ }^{*} \mathrm{U}=81 \cdot 0, \mathrm{P}=0 \cdot 0032 ;{ }^{* *} \mathrm{U}=84 \cdot 0, \mathrm{P}=0 \cdot 0041$.

TABLE II-Clinical features of patients with $R A$ and autonomic neuropathy
TABLE III-Clinical details of patients with $R A$ with and without autonomic neuropathy

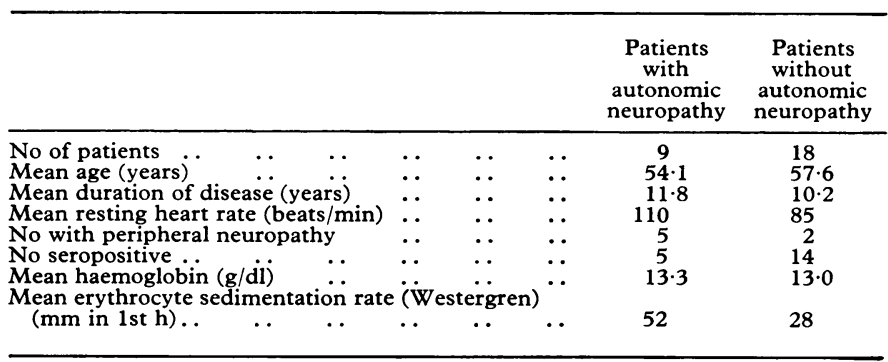

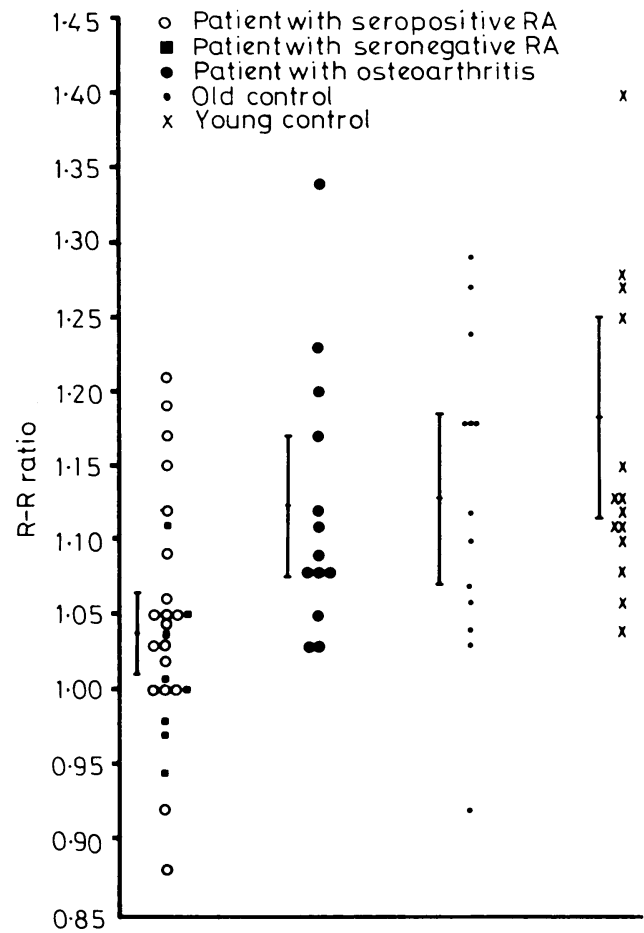

FIG 2-Scatter diagram of individual $R-R$ ratios in four groups studied, with means $\pm 2 \mathrm{SE}$ of means.

\begin{tabular}{|c|c|c|c|c|c|c|c|c|c|c|}
\hline $\begin{array}{l}\text { Case } \\
\text { No }\end{array}$ & Sex & $\underset{\text { (years) }}{\text { Age }}$ & $\begin{array}{l}\text { Duration of } \\
\text { disease } \\
\text { (years) }\end{array}$ & $\begin{array}{l}\text { Resting } \\
\text { heart rate } \\
\text { (beats } / \mathrm{min} \text { ) }\end{array}$ & $\begin{array}{l}\text { Peripheral } \\
\text { neuropathy }\end{array}$ & $\begin{array}{l}\text { Autonomic } \\
\text { neuropathy }\end{array}$ & $\begin{array}{l}\text { Sheep-cell } \\
\text { agglutination } \\
\text { test }\end{array}$ & $\begin{array}{l}\text { Haemoglobin } \\
(\mathrm{g} / \mathrm{dl})\end{array}$ & $\begin{array}{c}\text { Erythrocyte } \\
\text { sedimentation } \\
\text { rate } \\
\text { (Westergren) } \\
(\mathrm{mm} \text { in 1st h) }\end{array}$ & Treatment \\
\hline 1 & $\mathrm{~F}$ & 50 & 23 & 115 & $\begin{array}{l}\text { Hypoalgesia and } \\
\text { hypoaesthesia of } \\
\text { hands and feet }\end{array}$ & Postural hypotension & $+\mathrm{ve}$ & $13 \cdot 5$ & 60 & Prednisolone \\
\hline 2 & $\mathrm{~F}$ & 65 & 19 & 83 & $\begin{array}{l}\text { Hypoalgesia and } \\
\text { hypoaesthesia of } \\
\text { hands and feet }\end{array}$ & Postural hypotension & $+\mathrm{ve}$ & $12 \cdot 5$ & 35 & $\begin{array}{l}\text { Prednisolone, } \\
\text { gold }\end{array}$ \\
\hline 3 & $\mathrm{~F}$ & 58 & 15 & 125 & $\begin{array}{l}\text { Distal motor weakness, } \\
\text { hypoalgesia and } \\
\text { hypoaesthesia of } \\
\text { hands and feet }\end{array}$ & Gustatory sweating & $+\mathrm{ve}$ & $13 \cdot 0$ & 100 & Gold \\
\hline 4 & $\mathbf{F}$ & 54 & 5 & 103 & & & + ve & $12 \cdot 5$ & 58 & Penicillamine \\
\hline 5 & $\mathbf{F}$ & 22 & 4 & 140 & & & +ve & $12 \cdot 0$ & 110 & Aspirin \\
\hline 6 & $\mathbf{F}$ & 67 & 2 & 103 & Hypoalgesia of hands & $\begin{array}{l}\text { Postural hypotension, } \\
\text { gustatory sweating }\end{array}$ & - ve & $14 \cdot 7$ & 24 & $\begin{array}{l}\text { Penicillamine } \\
\text { Prednisolone }\end{array}$ \\
\hline 7 & $\mathbf{F}$ & 62 & 27 & 100 & $\begin{array}{l}\text { Hypoalgesia and } \\
\text { hypoaesthesia of } \\
\text { hands and feet }\end{array}$ & & - ve & $13 \cdot 0$ & 30 & Prednisolone \\
\hline 8 & $\mathrm{~F}$ & 61 & 4 & 130 & & & -ve & $15 \cdot 9$ & 21 & Penicillamine \\
\hline 9 & $\mathrm{~F}$ & 48 & 8 & 92 & & & -ve & $13 \cdot 0$ & 32 & Penicillamine \\
\hline
\end{tabular}


patients, including eight of the nine with RA who had R-R ratios of one or less. Seven of these had a Valsalva ratio of less than 1.50 . Levin $^{5}$ found that 192 out of 200 normal subjects had a Valsalva ratio of 1.50 or more. Fig 3 shows that the correlation between the lying-standing $\mathrm{R}-\mathrm{R}$ ratio and the Valsalva ratio was good.

Beat-to-beat variation-Beat-to-beat variation was investigated in five of the patients with RA who had R-R ratios of one or less and in three controls. Fig 4 shows recordings obtained in one patient (case 6) and a control (subject 2). The individual beat-to-beat variation scores were $8,7,3,6$, and 8 in cases $1,2,6,8$, and 9 respectively; and 18,18 , and 20 in control subjects 1,2 , and 3 respectively.

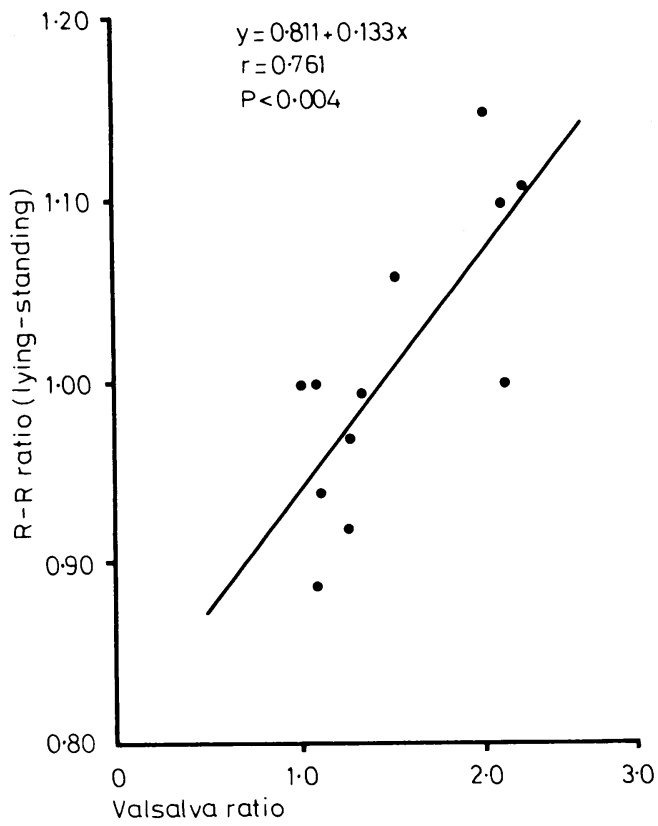

FIG 3-Correlation between $\mathrm{R}-\mathrm{R}$ ratios (lying-standing) and Valsalva ratios.

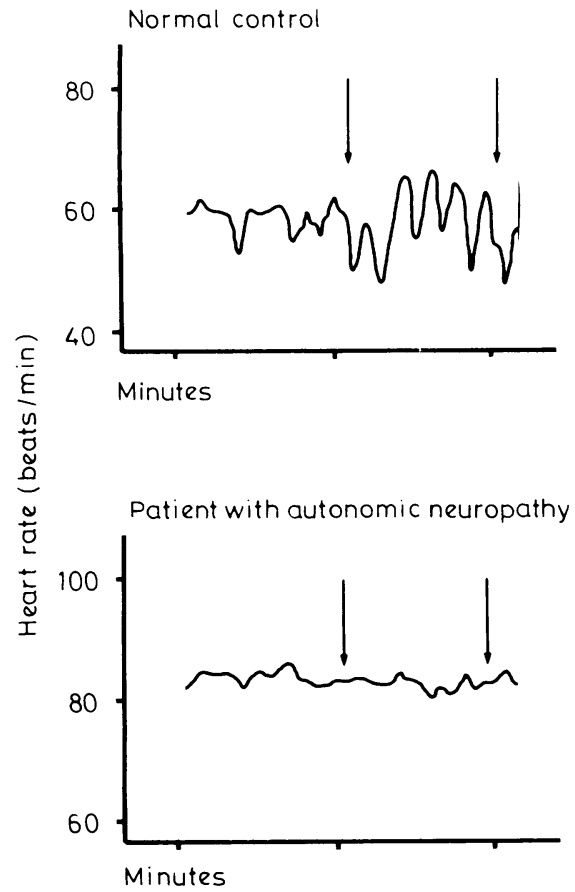

FIG 4-Recordings obtained in a normal control and a patient with RA and autonomic neuropathy. Time scale is shown in one-minute divisions. Arrows mark points between which deep breaths were taken.

\section{Discussion}

In the first part of the study we identified nine patients with RA who had a deficient heart-rate response to standing, indicating abnormal cardiovascular reflexes consistent with an autonomic neuropathy. Our results obtained with this test for autonomic neuropathy correlated with those of more established tests such as the Valsalva manoeuvre and the beat-to-beat variation with respiration.

Autonomic function becomes impaired with increasing age, ${ }^{8}$ but despite this significantly more patients with RA gave abnormal results to the tests when compared with age-matched groups of patients with osteoarthritis and normal controls. The mean ages of the patients with RA with and without abnormal autonomic function were comparable. The duration of the disease was similar in both groups, as was the mean haemoglobin concentration. Interestingly, however, the mean erythrocyte sedimentation rate was higher in the nine patients with autonomic neuropathy. Four of these patients had seronegative rheumatoid disease, and, as far as we are aware, autonomic neuropathy has not been described in such patients.

Ewing et $a l^{9}$ reported a definite relation between peripheral and autonomic neuropathy in diabetics, and we observed a similar association in this study, since five of the nine patients with RA who had an autonomic neuropathy also had clinical evidence of a peripheral neuropathy. Peripheral neuropathy is thought to be due to vasculitis in rheumatoid disease, ${ }^{10}$ and possibly an autonomic neuropathy occurs for the same reason and may even precede the development of a peripheral neuropathy. Furthermore, abnormal responses to tests of autonomic function may precede symptoms for some years in diabetics with autonomic neuropathy, ${ }^{11}$ and, interestingly, only four of our nine patients had symptoms that could be attributed to an autonomic neuropathy. Patients with RA may have minor subclinical cardiac abnormalities such as pericarditis, but we feel that these are unlikely to affect the cardiovascular reflexes under study. ${ }^{12}$

The presence of an autonomic neuropathy has been established as a poor prognostic factor in diabetes, since the frequency of unexplained cardiorespiratory arrests particularly during anaesthesia and in the immediate postoperative period appears to be increased in these patients. ${ }^{13}{ }^{14}$ This may also apply in RA, and long-term follow-up of our patients is essential to determine whether such risk factors do exist in rheumatoid autonomic neuropathy.

We thank Dr Richard Sutton and the staff of the ECG department at St Stephens Hospital for help and advice, the sister and staff of the rheumatic clinic, and Miss Eileen O'Sullivan for secretarial help.

\section{References}

${ }^{1}$ Hart, F D, and Golding, J R, British Medical fournal, 1960, 1, 1594.

${ }^{2}$ Kalliomäki, J L, Saarimaa, H A, and Toivanen, P, Annals of the Rheumatic Diseases, 1963, 22, 46.

${ }^{3}$ Bennett, P H, and Scott, J T, Annals of the Rheumatic Diseases, 1965, 24, 161.

${ }^{4}$ Ewing, D J, et al, British Medical fournal, 1978, 1, 145.

5 Levin, A B, American fournal of Cardiology, 1966, 18, 90

${ }^{6}$ Wheeler, T, and Watkins, P J, British Medical fournal, 1973, 4, 584.

${ }^{7}$ Ropes, M W, et al, Bulletin on Rheumatic Diseases, 1958, 9, 175.

${ }^{8}$ Appenzeller, O, and Descarries, L, New England fournal of Medicine, 1964, 271, 820.

${ }^{9}$ Ewing, D J, et al, fournal of Neurology, Neurosurgery, and Psychiatry, 1976, 39, 453.

10 Pallis, C A, and Scott, J T, British Medical fournal, 1965, 1, 1147.

${ }^{11}$ Ewing, D J, et al, Clinical Science and Molecular Medicine, 1974, 46, 295.

12 Bonfiglio, T, and Atwater, E C, Archives of Internal Medicine, 1969, 124, 714.

${ }^{13}$ Ewing, D J, Campbell, I W, and Clarke, B F, Lancet, 1976, 1, 601

${ }_{14}$ Page, M McB, and Watkins, P J, Clinics in Endocrinology and Metabolism, $1977,6,377$

(Accepted 7 fune 1979) 